\title{
Diagnosis of entrepreneurial competency of selected retailers in Chennai
}

\author{
S. Palaniappan ${ }^{1, *}$, Kavitha Shanmugam ${ }^{2}$ \\ ${ }^{1}$ Research Scholar, ${ }^{2}$ Research Supervisor Research \& Development Center, Bharathiar University, Coimbatore, ${ }^{\mathbf{1}}$ Ad-Hoc Faculty, National \\ Institute of Technology, Tiruchirappalli, Tamil Nadu, ${ }^{2}$ Associate Professor, School of Management, SRM Institute of Science \& \\ Technology, Kattankulathur, Kancheepuram, Tamil Nadu, India \\ *Corresponding Author: S. Palaniappan \\ Email: spalaniappanemail@gmail.com
}

\begin{abstract}
Retailing as an industry is undergoing phenomenon transformation in the wake of technological changes and Government policy initiatives. Retailers in general and small retailers, in particular, has to possess entrepreneurial competencies in order to survive and succeed in this turbulent environment. This paper is an attempt to diagnose the entrepreneurial competency of Provision store and Supermarket retailers in Chennai. The researcher collected data from 103 retailers and analyzed their level of entrepreneurial competency and its association with their demographic profile. The study reveals that retailers are not possessing a great deal of entrepreneurial competency. And the demographic profile of the respondents significantly impacts their entrepreneurial competencies.
\end{abstract}

Keywords: Entrepreneurial competency, Retailer, Provision stores, Supermarkets, Small business retailing.

\section{Introduction}

Richard Cantillon defined the entrepreneur as an individual who buys the produce from someone at a certain price and resells them at an uncertain price. (Cantillon, 1755). Apart from being a reseller, they also act as creators of innovative change in the society (Swedberg, 2009, Schumpeter, 1934; 1961). Entrepreneurs should possess a high degree of entrepreneurial competency. Entrepreneurial Competency is the capability of the entrepreneur to face a critical situation effectively in spite of environmental constraints, with the help of available resources. (Landström, H., 2007). Entrepreneurial competency is the individual traits, which result in venture success. (Bird, 1996)

For new entrepreneurs, the retail sector offers suitable entry option. (Davidson \& Steffens, 2011; Long, Yang, \& Gao, 2010). In today's circumstances, in the wake of globalization, technological changes and government policy changes, the retail sector is undergoing structural change. Competition in the retail industry has increased, and this requires efficiency and effectiveness (Corsten \& Gruen, 2003; Ellram, La Londe, \& Weber, 1999; van Zelst, S., van Donselaar, K, 2009). On the other hand, small unorganized retailers are unprepared to face growing competition. (Ali, J., Chandra, A., \& Ali, T., 2017). Role distinctive competencies of rural retailers will positively impact their competitive advantage (Mcgee and Finney 1997). This requires retailers to possess high degree of entrepreneurial competency.

\section{Literature Review}

The research on competency gained momentum with an article by McClelland on competence and intelligence (McClelland, 1973). Opportunity seeking competency, organizing competence, strategic competence, relationship competence, commitment competency and conceptual competency are the six facets of entrepreneurial competency (Man, T. W., Lau, T., \& Chan, K. F., 2002.) Entrepreneurial competencies significantly impact business performance and competitive ability (Man et al, 2002), business growth and success (Colombo and Grilli, 2005).

Retailers who possess a broad range of distinctive competencies are outperforming those with few competencies (McGee, J. E., Love, L. G., \& Festervand, T. A., 2000). There are several internal and external factors which will influence the grocery store retailer's business performance (Kumar, Karande, 2000). Distinctive entrepreneurial competence is significantly associated with the sustainable competitive advantage (Fernandez, A. I., Lara, P. R., Ugalde, M. C., \& Sisodia, G. S., 2018)

\section{Statement of the Problem}

Retailers should possess entrepreneurial competency in order to sustain and succeed in business. The presence of entrepreneurial competency will give the needed breathing space to survive the massive competition. The present study tries to analyze the degree of entrepreneurial competency of small retailers in Chennai across their demographic profile.

\section{Research Objectives}

1. To explore the relationship between the demographic profile of respondents, viz., gender, age, educational qualification, nature of ownership and Level of Entrepreneurial Competency

2. To study the Intra-relationship between the factors of entrepreneurial Competency among the selected respondents

\section{Research Hypothesis}

Ha1: There is a significant mean difference subsist between the demographic profile of respondents, like, gender, age, educational qualification and nature of ownership with respect to levels of entrepreneurial competency.

$\mathrm{Ha}$ 2: There is a significant association present among the factors of entrepreneurial competency between the selected retailers with special reference to retailers in Chennai. 


\section{Research Design}

The researcher carried out a descriptive analysis to explore the entrepreneurial competency of retailers in Chennai. The study is carried out in Tambaram taluk in Chennai. Provision store and Supermarket retailers operating with a floor space of 200-5000sq.ft and registered with Tamil Nadu traders association, (Tamil Nadu vanigar sangangalin peravai) are the population. Among the 4200 odd members, 115 respondents were selected as the sample through multistage area sampling. One hundred and three retailers completely filled up the questionnaires. Entrepreneurial Competency scale developed by Man et al., (2012) is adopted, and it is suitably adjusted for retailers with the contribution from Experts. It consists of Likert's scale questions, and the reliability of the constructs are tested with the help of Cron-bach alpha.

\section{Data Analysis}

This segment highlights the outcomes of data analysis performed, viz., frequency analysis, descriptive study, t-test, one-way ANOVA and Correlation Analysis.

\section{Frequency Analysis}

Table 1 depicts the profile of the samples regarding gender, age, educational qualification, nature of ownership, duration of business, and floor space of the retail store.

Table 1: Demographic profile of the respondents

\begin{tabular}{|c|c|c|c|}
\hline S. No & Particulars & Frequency & Percent \\
\hline \multirow[t]{4}{*}{1} & Gender & & \\
\hline & Male & 53 & 51.5 \\
\hline & Female & 50 & 48.5 \\
\hline & Total & 103 & 100.0 \\
\hline \multirow[t]{5}{*}{2} & Age group & & \\
\hline & Less than 30 Years & 20 & 19.4 \\
\hline & $30-45$ Years & 38 & 36.9 \\
\hline & More than 45 Years & 45 & 43.7 \\
\hline & Total & 103 & 100.0 \\
\hline \multirow[t]{6}{*}{3} & Educational Oualification & & \\
\hline & Up to HSE & 47 & 45.6 \\
\hline & ITI / Diploma & 15 & 14.6 \\
\hline & UG Degree & 29 & $\frac{17.0}{28.2}$ \\
\hline & PG Degree & 12 & 11.7 \\
\hline & Total & 103 & 100.0 \\
\hline \multirow{5}{*}{4} & & & \\
\hline & $\begin{array}{l}\text { Nature of Ownership } \\
\text { Partnership }\end{array}$ & 25 & 24.3 \\
\hline & Sole proprietorship & 48 & 46.6 \\
\hline & Family owned business & 30 & 29.1 \\
\hline & Total & 103 & 100.0 \\
\hline \multirow[t]{6}{*}{5} & Duration of the business & & \\
\hline & Less than 10 years & 20 & 19.4 \\
\hline & $11-20$ years & 34 & 33.0 \\
\hline & $21-30$ years & 20 & 19.4 \\
\hline & Above 30 Years & 29 & 28.2 \\
\hline & Total & 103 & 100.0 \\
\hline \multirow[t]{5}{*}{6} & Floor Space of Retail shop & & \\
\hline & $200-2000$ Sq.ft & 55 & 53.4 \\
\hline & $2001-3500$ Sq.ft & 38 & 36.9 \\
\hline & $3501-5000 \mathrm{Sq} . \mathrm{ft}$ & 10 & 9.7 \\
\hline & Total & 103 & 100.0 \\
\hline
\end{tabular}

Source: Primary data

From Table 1, it is seen that the number of male respondents (53 members) is a little more than the number of female respondents (50 members). Young respondents below the age of 30 years (20 persons) are the lowest whereas respondents who are more than 45 years of age are the leading 
group (45 persons). Respondents with PG qualification are the least (12 members) while those with HSE and below are the highest (47 members).

In the samples, the majority of the stores investigated are sole-proprietorship business (48 stores), whereas familyowned stores come next (30 stores) and partnership business are the least (25 shops). Retail stores who are functioning for 11 to 20 years are the maximum (34 stores). Majority of the stores are small size shops with floor space of 200-2000sq.ft
(55 stores) while mid-sized stores with floor space of 20013500sq.ft come next (38 stores), and large stores with floor space of 3501-5000sq.ft are very less (10 stores only).

\section{Entrepreneurial competency - Descriptive Study}

Descriptive study, like mean and standard deviation, has been analyzed and the outcomes have been shown in table 2 .

Table 2: Entrepreneurial competency - descriptive analysis

\begin{tabular}{|l|c|c|c|c|c|c|}
\hline \multicolumn{1}{|c|}{ Factors } & N & $\begin{array}{c}\text { Min. } \\
\text { Score }\end{array}$ & $\begin{array}{c}\text { Max. } \\
\text { Score }\end{array}$ & Mean & $\begin{array}{c}\text { Std. } \\
\text { Deviation }\end{array}$ & $\begin{array}{c}\text { Cron-Bach } \\
\text { Alpha }\end{array}$ \\
\hline Opportunity Seeking Competency & 103 & 4 & 20 & 11.88 & 4.843 & .877 \\
\hline Relationship Competency & 103 & 6 & 30 & 18.83 & 7.000 & .730 \\
\hline Conceptual Competency & 103 & 7 & 35 & 20.46 & 7.839 & .768 \\
\hline Organizing Competency & 103 & 10 & 50 & 31.52 & 11.746 & .733 \\
\hline Strategic Competence & 103 & 9 & 45 & 25.70 & 11.893 & .802 \\
\hline Commitment Competency & 103 & 4 & 20 & 11.72 & 5.040 & .727 \\
\hline Entrepreneurial Competency & 103 & 40 & 200 & 120.12 & 40.350 & .796 \\
\hline
\end{tabular}

Source: Primary data

Table 2 shows the descriptive study of entrepreneurial competency. The mean of all the dimensions is in the average range. They are neither on the maximum side nor on the minimum side. It shows that retailers are having the average level of competency only. All the six facets of entrepreneurial competency are having Cron-bach alpha greater than 0.7, and it confirms the reliability of the constructs.
Association between Gender and Dimensions of Entrepreneurial Competency

The relationship between retailers' gender and the dimensions of entrepreneurial competency is explored by using independent sample t-test, and the results thereof are shown.

Ha1: There is a significant mean difference subsist between the respondent's gender and the levels of entrepreneurial competency.

Table 3: Gender and level of entrepreneurial competency

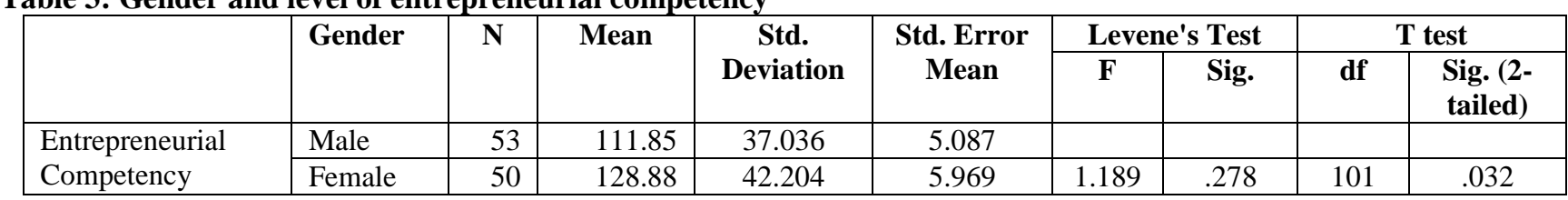

Source: Primary data

Table 3 highlights Levene's test for equality of variances and t-test outcomes. For ensuring homogeneity between groups, Levene's test of significance should be higher than 0.05 , and in the present case, it is 0.278 which shows homogeneity between the two groups at 0.05 level of significance. Since P-value .032 is less than 0.05 level of significance the alternative hypothesis is accepted. There is a significant mean difference exist among the gender concerning their level of entrepreneurial competency.

\section{Association between Age of retailers and Level of Entrepreneurial Competency}

The level of entrepreneurial competency concerning the age of the retailers is analyzed using one-way ANOVA, and the results are exhibited in table 4.

Ha1: There is a significant mean difference subsists between the respondent's age and their level of entrepreneurial competency.

Table 4: Age of retailers and levels of entrepreneurial competency

\begin{tabular}{|c|c|c|c|c|c|c|c|c|c|}
\hline & \multirow{2}{*}{$\begin{array}{c}\text { Age of } \\
\text { Retailers }\end{array}$} & \multirow[b]{2}{*}{$\mathbf{N}$} & \multirow[b]{2}{*}{ Mean } & \multirow{2}{*}{$\begin{array}{c}\text { Std. } \\
\text { Deviation }\end{array}$} & \multirow[b]{2}{*}{ Std. Error } & \multicolumn{2}{|c|}{ Test of Homogeneity } & \multicolumn{2}{|c|}{ ANOVA } \\
\hline & & & & & & $\begin{array}{c}\text { Levene's } \\
\text { Statistic }\end{array}$ & p value & F value & p value \\
\hline \multirow{4}{*}{$\begin{array}{l}\text { Entrepreneurial } \\
\text { Competency }\end{array}$} & $<30$ & 20 & 102.75 & 35.406 & 7.917 & \multirow{4}{*}{2.939} & \multirow{4}{*}{.058} & \multirow{4}{*}{3.994} & \multirow{4}{*}{.021} \\
\hline & $30-45$ & 38 & 116.03 & 45.392 & 7.364 & & & & \\
\hline & $>45$ & 45 & 131.29 & 34.944 & 5.209 & & & & \\
\hline & Total & 103 & 120.12 & 40.350 & 3.976 & & & & \\
\hline
\end{tabular}

Source: Primary data 
In the above Table 4 group descriptive analysis, the test of homogeneity, and ANOVA test results are shown. Levine's test of homogeneity indicates a p value of .058 which is above 0.05 and therefore homogeneity of variance is not significant. The $\mathrm{p}$ value in ANOVA is .021 which is less than 0.05; it shows that alternative hypothesis (Ha1) is accepted at 0.05 level of significance. Hence it is confirmed that there is a significant mean difference exists between the retailer's age and their level of Entrepreneurial competency.

\section{Association between Education and Level of} Entrepreneurial Competency

The difference in the level of entrepreneurial competency with respect to the educational qualification of the respondents is given in table 5

Ha1: There is a significant mean difference subsists between respondent's educational qualification and their level of entrepreneurial competency.

Table 5: Educational qualification and levels of entrepreneurial competency

\begin{tabular}{|c|c|c|c|c|c|c|c|c|c|}
\hline & \multirow{2}{*}{$\begin{array}{l}\text { Nature of } \\
\text { Ownership }\end{array}$} & \multirow[b]{2}{*}{$\mathbf{N}$} & \multirow[b]{2}{*}{ Mean } & \multirow{2}{*}{$\begin{array}{c}\text { Std. } \\
\text { Deviation }\end{array}$} & \multirow[b]{2}{*}{ Std. Error } & \multicolumn{2}{|c|}{ Test of Homogeneity } & \multicolumn{2}{|c|}{ ANOVA } \\
\hline & & & & & & $\begin{array}{l}\text { Levene's } \\
\text { Statistic }\end{array}$ & p value & F value & p value \\
\hline \multirow{5}{*}{$\begin{array}{l}\text { Entrepreneurial } \\
\text { Orientation }\end{array}$} & Up to HSE & 47 & 109.19 & 32.868 & 4.794 & \multirow{5}{*}{2.624} & \multirow{5}{*}{0.055} & \multirow{5}{*}{3.801} & \multirow{5}{*}{.013} \\
\hline & ITI / Diploma & 15 & 118.47 & 48.997 & 12.651 & & & & \\
\hline & UG Degree & 29 & 126.55 & 38.684 & 7.183 & & & & \\
\hline & PG Degree & 12 & 149.42 & 46.426 & 13.402 & & & & \\
\hline & Total & 103 & 120.12 & 40.350 & 3.976 & & & & \\
\hline
\end{tabular}

Source: Primary data

The above Table 5, highlights the group descriptive analysis, the test of homogeneity, and ANOVA test outcomes. Levine's test gives a $\mathrm{p}$ value of 0.055 which is above 0.05 , and hence homogeneity of variance is not present. ANOVA test shows a p-value of .013, which is below .05 and therefore null hypothesis (H1) is rejected at 0.05 level of significance. It is proved that the respondent's entrepreneurial competency is significantly dependent on their educational qualification.

\section{Association between Nature of ownership and Level of Entrepreneurial Competency}

The degree of entrepreneurial competence with respect to the nature of ownership is analyzed using one-way ANOVA, and the results are given in table 5 .

Ha1: There is a significant mean difference subsists between the nature of ownership and the respondent's level of entrepreneurial competency.

Table 6: Nature of ownership and levels of entrepreneurial competency

\begin{tabular}{|c|c|c|c|c|c|c|c|c|c|}
\hline & \multirow[b]{2}{*}{$\begin{array}{l}\text { Nature of } \\
\text { Ownership }\end{array}$} & \multirow[b]{2}{*}{$\mathbf{N}$} & \multirow[b]{2}{*}{ Mean } & \multirow[b]{2}{*}{$\begin{array}{c}\text { Std. } \\
\text { Deviation }\end{array}$} & \multirow[b]{2}{*}{ Std. Error } & \multicolumn{2}{|c|}{ Test of Homogeneity } & \multicolumn{2}{|c|}{ ANOVA } \\
\hline & & & & & & $\begin{array}{l}\text { Levene's } \\
\text { Statistic }\end{array}$ & p value & F value & $p$ value \\
\hline \multirow{4}{*}{$\begin{array}{l}\text { Entrepreneurial } \\
\text { Orientation }\end{array}$} & $\begin{array}{c}\text { Partnership } \\
\text { Business }\end{array}$ & 25 & 122.56 & 41.922 & 8.384 & \multirow{4}{*}{2.900} & \multirow{4}{*}{0.060} & \multirow{4}{*}{0.805} & \multirow{4}{*}{.450} \\
\hline & Sole proprietorship & 48 & 123.75 & 44.244 & 6.386 & & & & \\
\hline & $\begin{array}{l}\text { Family owned } \\
\text { business }\end{array}$ & 30 & 112.27 & 31.760 & 5.799 & & & & \\
\hline & Total & 103 & 120.12 & 40.350 & 3.976 & & & & \\
\hline
\end{tabular}

Source: Primary data

Table 6, presents group descriptive analysis, the test of homogeneity and ANOVA test outcome. Levene's test of homogeneity gives a $\mathrm{p}$ value of 0.060 . It is above 0.05 which proves homogeneity of variance is not significant. Anova test gives a p-value of .450 , p-value more than 0.05 shows that the null hypothesis is not rejected at 0.05 level of significance. Hence nature of ownership does not significantly affect their entrepreneurial competency.

\section{Intra-relationship between the facets of entrepreneurial competency within the selected retailers}

The intra-relationship between the components of entrepreneurial competency among the selected retailers have been studied through Pearson Correlation Analysis.
Ha2: There is a significant association present among the factors of entrepreneurial competency between the selected retailers with special reference to retailers in Chennai. 
Table 7: Intra-relationship among the factors of entrepreneurial competency within the selected retailers

\begin{tabular}{|c|c|c|c|c|c|c|}
\hline Entrepreneurial Competency & 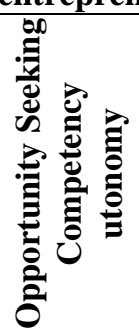 & 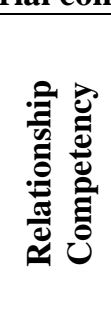 & 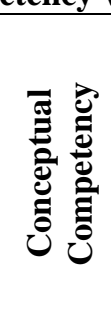 & 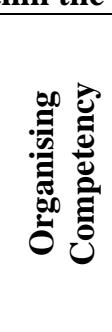 & 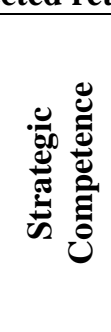 & 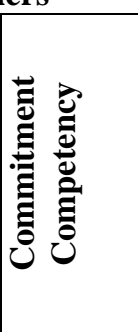 \\
\hline Opportunity Seeking Competency & 1 & $.614 * *$ & $.623^{* *}$ & $.571 * *$ & $.505^{* *}$ & $.668 * *$ \\
\hline Relationship Competency & $.614 * *$ & 1 & $.595 * *$ & $.586 * *$ & $.709 * *$ & $.635 * *$ \\
\hline Conceptual Competency & $.623 * *$ & $.595 * *$ & 1 & $.591 * *$ & $.694 * *$ & $.628 * *$ \\
\hline Organising Competency & $.571 * *$ & $.586 * *$ & $.591 * *$ & 1 & $.648^{* *}$ & $.631 * *$ \\
\hline Strategic Competence & $.505^{* *}$ & $.709 * *$ & $.694 * *$ & $.648 * *$ & 1 & $.639 * *$ \\
\hline Commitment Competency & $.668^{* *}$ & $.635 * *$ & $.628 * *$ & $.631 * *$ & $.639 * *$ & 1 \\
\hline Entrepreneurial Competency & $.746 * *$ & $.822 * *$ & $.827 * *$ & $.846^{* *}$ & $.882 * *$ & $.809 * *$ \\
\hline
\end{tabular}

P.S: **. Correlation is significant at the 0.01 level (1-tailed).

Table 7 shows the intra-relationship within factors of entrepreneurial competency among the selected retailers in Chennai. Through the table, it is seen that all the elements are inter-correlated at 0.01 level of significance and they are also correlated with entrepreneurial competency at 0.01 level of significance.

Intra-relationship is highest between relationship competency and strategic competency at $70.9 \%$ while it is lowest among opportunity seeking competency and strategic competency with $50.5 \%$. It is found that strategic competency with $88.2 \%$ correlation, is the leading factor in correlating with entrepreneurial competency and opportunity seeking competency is the least associated factor with $74.6 \%$.

This shows the validity of the alternative hypothesis. There is a significant relationship exist between factors of entrepreneurial competency within the selected retailers in Chennai.

\section{Results and Discussions}

The descriptive study of respondent's demographic profile shows that the majority of respondents are male. Majority of them are in the age group of more than 45 years. Most of the respondents have finished up to or below HSE only while those with PG qualification are the least. Majority of the stores are sole proprietorship business, and most of them are functioning for 11 to 20 years. The mean of entrepreneurial competency of the selected retailers is in the average range only. They do not possess high degree of entrepreneurial competency.

The study on the relationship between demographic profile of the respondent's and their entrepreneurial competency shows that gender, age and educational qualification are associated with entrepreneurial competency at 0.05 level of significance. Whereas nature of ownership is not significantly influencing their entrepreneurial competency. Thus, most of the demographic profile factors barring nature of ownership are influencing entrepreneurial competency.

While studying the inter-relationship between entrepreneurial competency factors, it is found that all the dimensions of entrepreneurial competency are significantly correlated and each dimension is correlated substantially with entrepreneurial competency. This substantiates the part findings of McGee, J. E., \& Peterson, M., (2000). Where they found that entrepreneurial competency factors are strongly correlated and they are positively related to firm performance.

\section{Conclusion}

Entrepreneurial competency is a key variable that influences organizational capability, competitive scope, and firm performance. (Sánchez, José. 2012). The present study throws light on the degree of entrepreneurial competency of retailers in Chennai. The entrepreneurial competency of small retailers in Chennai is in the average range only, and their demographic profile significantly influences their entrepreneurial competency. Retailers should focus on improving their entrepreneurial competency.

\section{References}

1. Ali J, Chandra A, Ali T. Self-started versus Family Inherited Businesses: A Comparison of Managing Unorganized Food Grocery Retail Stores in an Emerging Economy. Business Perspectives and Research. 2017;5(1):24-35.

2. Bird B. Towards a Theory of Entrepreneurial Competency in Advances in Entrepreneurship, Firm Emergence and Growth, 2:51-72. Greenwich, CN: JAI Press Inc. 1996.

3. Cantillon R. Première partie. Essai sur la nature du commerce en général. 1755:1-5.

4. Colombo MG, Grilli L. Founders' human capital and the growth of new technology-based firms: A competence-based view. Research policy. 2005;34(6):795-816.

5. Corsten D, Gruen T. Desperately seeking shelf availability: an examination of the extent, the causes, and the efforts to address retail out-of-stocks. International Journal of Retail \& Distribution Management. 2003;31(12):605-617.

6. Davidsson P, Steffens P. Comprehensive Australian Study of Entrepreneurial Emergence (CAUSEE): project presentation and early results. In New Business Creation 2011 (pp. 27-51). Springer, New York, NY.

7. Ellram LM, La Londe BJ, Weber MM. Retail logistics. International Journal of Physical Distribution \& Logistics Management. 1999;29(7):477-494. 
8. Fernandez AI, Lara PR, Ugalde MC, Sisodia GS. Distinctive competencies and competency-based management in regulated sectors: A methodological proposal applied to the pharmaceutical retail sector in Spain. Journal of Retailing and Consumer Services. 2018;42:29-36.

9. Kumar V, Karande K. The effect of retail store environment on retailer performance. Journal of business research. 2000;49(2):167-181.

10. Landström H. Entrepreneurship, competitiveness and local development: frontiers in European entrepreneurship research. Edward Elgar Publishing; 2007.

11. Long D, Yang J, Gao J. Anatomy of nascent entrepreneurship in China: a preliminary study from CPSED project. Journal of Chinese Entrepreneurship. 2010;2(2):129-147.

12. Man TW, Lau T, Chan KF. The competitiveness of small and medium enterprises: A conceptualization with focus on entrepreneurial competencies. Journal of business venturing. 2002;17(2):123-42.

13. McClelland DC. Testing for competence rather than for" intelligence." American psychologist. 1973;28(1):1.

14. McGee JE, Finney BJ. Competing against retailing giants: A look at the importance of distinctive marketing competencies. Journal of business and entrepreneurship. 1997;9(1):59.

15. McGee JE, Love LG, Festervand TA. Competitive advantage and the independent retail pharmacy: the role of distinctive competencies. Journal of Pharmaceutical Marketing \& Management. 2000;13(3):31-46.
16. McGee JE, Peterson M. Toward the development of measures of distinctive competencies among small independent retailers. Journal of Small Business Management. 2000;38(2):19.

17. Sánchez J. The influence of entrepreneurial competencies on small firm performance. Revista Latinoamericana de Psicología. 2012;44(2):165-77.

18. Schumpeter JA. The theory of economic developments: an inquiry into profits, capital, credit, interest, and the business cycle. Harvard University Press; 1961/1934.

19. Swedberg R. Rebuilding Schumpeter's theory of entrepreneurship. Marshall and Schumpeter on evolution. 2009:188-203

20. Van Zelst S, Van Donselaar K, Van Woensel T, Broekmeulen R, Fransoo J. Logistics drivers for shelf stacking in grocery retail stores: Potential for efficiency improvement. International Journal of Production Economics. 2009;121(2):620-32.

How to cite this article: Palaniappan S, Shanmugam K. Diagnosis of entrepreneurial competency of selected retailers in Chennai. J Manag Res Anal. 2018;5(4):436-441. 